Informatio: Journal of Library and Information Science Vol. 1(1), 83-98, Januari 2021

ISSN 2775-0043 (Online)

\title{
Grab and go alternatif layanan peminjaman buku Pustakalana Children's Library di masa pandemi
}

\author{
Zahra Fahira Iskandar ${ }^{*}$, Sukaesih ${ }^{\mathrm{b}}$, Evi Nursanti Rukmanac, Samson CMS ${ }^{\mathrm{d}}$ \\ abcd Fakultas Ilmu Komunikasi Universitas Padjadjaran Bandung
}

\begin{abstract}
Abstrak
Munculnya pandemi Covid-19 telah mengubah semua aspek kehidupan, di mana aktivitas setiap individu menjadi terbatas. Pembatasan aktivitas berkumpul disatu tempat membawa dampak besar bagi seluruh aspek kehidupan. Berbagai sektor di Indonesia seperti logistik, kesehatan, perkantoran, pelayanan informasi, pendidikan serta sektor kebutuhan hidup lainnya mengharuskan mencari alternatif lain untuk tetap bertahan harus dilakukan tanpa bertemu secara langsung. Pembatasan sosial berskala besar yang dikenal dengan istilah PSBB berdampak pada salah satu pelayanan publik: perpustakaan, dari berbagai jenis perpustakaan yaitu salah satunya adalah perpustakaan khusus terdampak kebijakan sosial terutama di bidang layanan peminjaman buku. Salah satu perpustakaan khusus yang terdampak di bidang ini adalah perpustakaan anak Pustakalana Children's Library di kota Bandung. Metode penelitian menggunakan kualitatif melalui studi kasus. Teknik pengumpulan data menggunakan teknik wawancara mendalam serta studi literatur. Informan yang diwawancarai ialah Direktur Pustakalana Children's Library, Pengguna Pustakalana Children's Library dan Pustakawan Pustakalana Children's Library. Hasil penelitian ini adalah Pustakalana Children's Library mengeluarkan sebuah inovasi layanan peminjaman buku daring yang inovatif di tengah Covid-19: Grab and Go. Layanan ini diciptakan oleh Pustakalana Children's Library sebagai akibat dari pembatasan sosial berskala besar di kota Bandung. Grab and Go merupakan layanan sirkulasi berbasis daring, di mana pemustaka di perbolehkan meminjam buku dari rumah dengan mengakses halaman web yang telah disediakan. Buku yang dipinjam kemudian akan dikirimkan oleh Pustakalana menuju alamat pemustaka. Dengan adanya layanan Grab and Go, Pustakalana tetap dapat menjalankan kegiatan sirkulasi walau ditengah kondisi pembatasan sosial akibat Covid-19 dan semakin memudahkan penyebaran informasi, khusunya buku anak kepada para pemustaka Pustakalana Children's Library Bandung.
\end{abstract}

Kata kunci: Sirkulasi daring; Perpustakaan khusus; Pandemi

Korespondensi: Zahra Fahira Iskandar, Fakultas Ilmu Komunikasi, Universitas Padjadjaran, Jl. Ir. Soekarno Km. 21, Jatinangor, Sumedang, Jawa Barat 45363, Indonesia

Email: zahra19007@mail.unpad.ac.id

http://jurnal.unpad.ac.id/informatio

DOI: https://doi.org/10.24198/inf.v1i1.31740

Received: Januari 2021; Accepted: Januari 2021; Published: Januari 2021

(C) Informatio 2021. This is an open access article under the CC BY-SA license 


\title{
Grab and go an alternative service for lending Pustakalana Childrens Library books during a pandemic
}

\begin{abstract}
The emergence of the Covid-19 pandemic has changed all life aspects, in which each individual's activity is now constrained. Limiting activities to gather in one place has a big impact on all life aspects as well. Various sectors in Indonesia, such as logistics, health, offices, information services, education, and other life necessities are forced to find alternative solution in order to survive even if it were done without direct contact. Large-scale social restrictions known as PSBB have an impact on one of the public information services: libraries, one of which is a special libraries that is affected by social policies, especially in the book lending services. One of the special libraries that is affected in this field is the children's library Pustakalana Children's Library in Bandung. The research method used was qualitative with case study approach. Data were collected through in-depth interviews and literature review. The respondents interviewed were the director, visitors, and librarian of Pustakalana Children's Library. The result of this research is that Pustakalana Children's Library issued an innovative online book lending service amid Covid-19: Grab and Go. This services was created by the library as a result of large-scale social restrictions in Bandung. Grab and Go is an online-based circulation service, in which users are allowed to borrow books from home by accessing the provided web page. Books that are borrowed then will be sent by Pustakalana to the user's address. With the Grab and Go service, Pustakalana is still able to carry out circulation activities even in the midst of social restrictions due to COVID-19 and makes it easier to disseminate information, particularly children's books to visitors Pustakalana Children's Library Bandung.
\end{abstract}

Key words: Online circulation; Special library; Pandemic

\section{PENDAHULUAN}

Menembus penjuru langit berkelana antar benua. Berbahaya dan mampu mengurangi populasi manusia secara perlahan. Ribuan manusia dibuat takluk oleh keberadaannya, yaitu Virus Corona atau yang saat ini dikenal Covid-19. Virus ini menyebabkan Pandemi di muka bumi. Per 20 Oktober 2020 sebanyak 40,6 juta orang dinyatakan terinfeksi Covid-19 di dunia (Azanella, 2020). Virus mematikan yang menyerang saluran pernapasan. Virus ini menyebar melalui tetesan air liur, cairan hidung saat orang bersin atau batuk perlahan dapat memasuki tubuh manusia (WHO, 2020). Diketahui awal mula Virus ini terdeteksi pertama kali di Wuhan Cina kemudian menyebar hampir ke seluruh Negara yang ada di muka bumi ini.

Virus Covid-19 kemudian berhasil masuk ke Indonesia. Kasus awal Covid-19 terdeteksi di Indonesia ialah pada tanggal 2 Maret 2020 dengan ditemukannya 2 orang yang terinfeksi Covid-19 (Pranita, 2020). Setelah ditemukan 2 orang terdeteksi Covid-19 pemerintah memberikan instruksi kepada seluruh kota di Indonesia untuk melakukan Pembatasan Sosial Berskala Besar atau disingkat menjadi PSBB. PSBB diterapkan oleh pemerintah dengan tujuan untuk menurunkan penyebaran virus Covid-19 di Indonesia. Semua elemen masyarakat diharuskan untuk mengurangi interaksi secara langsung serta

Grab and go alternatif layanan peminjaman buku Pustakalana Children's Library di masa pandemi (Zahra Fahira Iskandar, Sukaesih, Evi Nursanti Rukmana, Samson CMS) 
berkerumun di suatu tempat. Pelaksanaan PSBB dilakukan di setiap daerah yang berbeda-beda. Kota Bandung, Kota Cimahi, Kabupaten Bandung, Kabupaten Bandung Barat dan Kabupaten Sumedang mulai pelaksanaan PSBB pada Rabu, 22 April 2020 (Rajasa, 2020).

Efek dari PSBB ini berpengaruh terhadap sektor logistik, kesehatan, ekonomi, keuangan, pelayanan informasi, pendidikan serta sektor penting lainnya. Setiap sektor diharuskan untuk menciptakan jalan keluar akibat dari pembatasan bersosial untuk tetap dapat memenuhi kebutuhan masing-masing sektor meski dilakukan tanpa bertemu secara langsung. PSBB ini berdampak kepada salah satu pelayanan kebutuhan informasi masyarakat yaitu Pustakalana Children's Library. Pustakalana Children's Library merupakan perpustakaan komunitas berbasis perpustakaan anak. Perpustakaan ini didirikan oleh Puti Cheniza Sapphira pada tanggal 1 Desember 2015 di Kota Bandung yang berlokasi di Jl. Taman Cibeunying Selatan No. 45 Bandung 40114, Selaras Guest House lantai 2. Pelayanan Pustakalana Children's Library berfokus kepada pelayanan kebutuhan koleksi bacaan khusus anak-anak dan mempunyai 65.033 buku, akan tetapi yang diperbolehkan untuk dipinjam oleh pemustaka ialah sebanyak 2.500 buku. Seluruh koleksi buku terdiri atas buku khusus anak-anak, fiksi remaja dan terdapat beberapa buku mengenai parenting. Akibat pandemi ini pelayanan peminjaman koleksi menjadi terhambat dikarenakan ada pembatasan sosial Bandung Raya pada tanggal 22 April 2002. Buku sebanyak 2.500 menjadi sulit untuk digunakan oleh pemustaka. Maka dari itu Pustakalana memutuskan untuk membuat kebijakan baru agar anak-anak di rumah tetap dapat meminjam koleksi Pustakalana. Hasil pembuatan kebijakan baru tersebut adalah layanan Grab and Go yang menjadi jembatan penghubung antara pemustaka di rumah dengan Pustakalana Children's Library.

Berdasarkan pengertian dari Encyclopedia Britannica Micropedia perpustakaan merupakan kumpulan buku atau koleksi fisik lainnya yang dikumpulkan dalam satu ruangan. Definisi perpustakaan pun dikeluarkan oleh Webster's Third Edition International Dictionary edisi 1961 dalam Sulistyo-Basuki (1991) yaitu kumpulan manuskrip, buku serta bahan koleksi pustaka lainnya yang digunakan untuk keperluan penelitian, pencarian ilmu pengetahuan, dan rekreasi. Kedua pendapat mengenai definisi perpustakaan menjelaskan mengenai keadaan suatu perpustakaan yang dilihat dari bentuk fisiknya. Definisi perpustakaan menurut International Federation of Library Associations and Institutions (IFLA) mencakup bahan koleksi berbentuk fisik maupun digital (non-cetak) yang disusun secara teratur dan sistematis. Ketiga definisi mengenai 
perpustakaan mengarah kepada suatu pusat informasi yang berisi berbagai jenis ilmu pengetahuan yang dikemas secara beragam baik secara cetak maupun non cetak.

Berbagai jenis koleksi sesuai dengan kebutuhan pemakai koleksi buku atau pun koleksi dalam bentuk lainnya yang termasuk ke dalam fasilitas perpustakaan atau istilah lainnya pemustaka (Loho, Tabaga, \& Harinda, 2016), mengakibatkan terbentuknya jenis-jenis perpustakaan sesuai dengan isi koleksi nya. Sebagaimana yang dijelaskan oleh Sulistyo-Basuki (1991) membagi perpustakaan menjadi tujuh jenis yaitu:

1. Perpustakaan Internasional. Perpustakaan ini didirikan berdasarkan kerja sama antar Negara. Seperti perpustakaan Sekretariat ASEAN di Jakarta.

2. Perpustakaan umum. Perpustakaan ini memiliki ciri-ciri terbuka untuk siapa pun tidak memandang umur, jenis kelamin, agama, dan pekerjaan. Perpustakaan umum ini biasanya di danai dan dikelola oleh pemerintah. Serta jasa layanan perpustakaan yang diberikan dapat diakses kapan pun dan oleh siapa pun tanpa dipungut biaya.

3. Perpustakaan Nasional. Sulistyo-Basuki (1991) menjelaskan bahwa definisi perpustakaan Nasional dapat dilihat sesuai dengan fungsinya sebagai penyimpan semua koleksi yang diterbitkan suatu Negara.

4. Perpustakaan Perguruan Tinggi. Perpustakaan yang bertujuan atas nama Tri Dharma Perguruan Tinggi.

5. Perpustakaan Sekolah. Perpustakaan yang memiliki tujuan selaras dengan lembaga pendidikan yang menaungi nya. Seperti perpustakaan TK, SD, SMP, dan SMA.

6. Perpustakaan Khusus. Perpustakaan yang memiliki subjek koleksi terbatas sesuai dengan lembaga yang menaungi. Sulistyo-Basuki (1991) membagi perpustakaan khusus menjadi perpustakaan lembaga Negara, surat kabar, bank, perusahaan, militer, lembaga penelitian, organisasi massa, industri, badan komersial dan perguruan tinggi. Namun perpustakaan khusus pun dapat dilihat berdasarkan kelompok tertentu tidak hanya berfokus kepada suatu lembaga yang ada di pemerintahan.

7. Perpustakaan pribadi atau swasta. Perpustakaan ini melayani kelompok, atau individu tertentu. Dikarenakan perpustakaan ini dikelola secara swasta, maka setiap anggota perpustakaan diminta untuk membayar iuran sesuai dengan periode yang telah ditentukan oleh kebijakan masing-masing perpustakaan.

Pada hakikatnya setiap perpustakaan memiliki aktivitas kerjanya sesuai dengan kebutuhan masing-masing jenis perpustakaan. Namun secara umum sebagaimana yang dijelaskan oleh Sukaesih (2020) dalam bahan pengajaran nya mengenai layanan informasi dan perpustakaan dijelaskan bahwa aktivitas kerja perpustakaan terbagi menjadi tiga tahap yaitu a) Collect. Tahap ini mencakup analisis kebutuhan informasi 
publik. b) Organization. Bagaimana seorang pustakawan mengorganisir bahan pustaka dengan cara inventaris data, klasifikasi maupun katalogisasi. c) Dissemination. Peran layanan informasi dan perpustakaan, pada tahap ini memiliki andil besar dalam upaya penyebarluasan bahan pustaka kepada pemustaka.

Mengacu kepada KBBI bahwa kata "Layanan" memiliki dasar kata "Layan" yang bermakna membantu menyiapkan suatu hal atau mengurus apa yang diperlukan oleh seseorang. Dengan begitu layanan perpustakaan memiliki definisi suatu aktivitas membantu atau mengurus yang bertujuan untuk pemenuhan kebutuhan informasi pemustaka di perpustakaan. Kemudian menurut Darmono pada buku "Akses dan Layanan Perpustakaan" yang ditulis oleh Rahmah (2018) menjelaskan bahwa pada hakikatnya sebuah layanan perpustakaan mencakup seluruh bentuk informasi yang dibutuhkan oleh pemustaka yang digunakan di dalam perpustakaan ataupun untuk dibawa pulang ke rumah dan penelusuran kebutuhan informasi pengguna. Pelayanan perpustakaan menjadi ujung tombak dalam proses penyebarluasan informasi yang dimiliki oleh perpustakaan kepada pemustaka. Jenis-jenis layanan perpustakaan terdiri atas layanan fotokopi, layanan ruang baca, layanan koleksi khusus, layanan sirkulasi, layanan abstrak dan indeks, layanan referensi dan layanan informasi mutakhir.

Layanan peminjaman koleksi buku Pustakalana maka layanan tersebut termasuk ke dalam layanan sirkulasi. Menurut Wulandari, Rohanda, \& Sumiati (2012) layanan sirkulasi merupakan layanan perpustakaan yang mencatat kegiatan pemustaka ketika memanfaatkan serta menggunakan koleksi perpustakaan yang tepat sasaran dan tepat waktu demi kelancaran pemakaian koleksi perpustakaan oleh pemustaka. Berdasarkan definisi yang diungkapkan oleh Lasa HS dapat di identifikasi kegiatan kerja layanan sirkulasi meliputi tata cara peminjaman, pencatatan pendaftaran pemustaka yang akan meminjam koleksi, pencatatan waktu peminjaman, denda pemustaka, serta mengawasi terhadap buku-buku yang rawan untuk dipinjam ke rumah. Menurut Hartono (2016) terdapat tujuh kegiatan layanan sirkulasi meliputi:

1. Pendaftaran peminjaman. Mengetahui jati diri peminjam, mengetahui golongan kebutuhan peminjam, dan mengukur daya guna perpustakaan bagi yang dilayaninya.

2. Prosedur peminjaman. Mengamankan koleksi, mengetahui siapa peminjam buku, mengetahui jumlah buku yang dipinjam dan mengetahui batas waktu pengembalian buku.

3. Pemungutan denda.

4. Pengawasan buku yang terbatas koleksinya. 
5. Waktu peminjaman.

6. Statistik peminjaman. Statistik peminjaman bertujuan untuk menentukan kebijakan perpustakaan.

7. Pinjam Antar-Perpustakaan.

Sulistyo-Basuki (1991) menjelaskan tugas bagian layanan sirkulasi meliputi a) Mengawasi pintu keluar dan masuk perpustakaan. Setiap pustakawan harus selalu waspada mengamati pemustaka yang keluar dan masuk perpustakaan. b) Mencatat pendaftaran, perpanjangan serta pengunduran diri anggota. Pustakawan harus meminta pemustaka untuk mengisi formulir identitas dan permintaan lainnya. Baru kemudian pemustaka dapat mendapat kartu keanggotaan. Setiap perpustakaan memiliki kebijakan ketika akan menerima pemustaka menjadi anggota, terdapat perpustakaan yang meminta bayaran iuran ketika ingin menjadi anggota perpustakaan. c) Melakukan pencatatan terhadap pengembalian, peminjaman serta perpanjangan buku. d) Pustakawan akan menarik dengan sejumlah uang yang sudah ditentukan untuk buku yang terlambat dikembalikan. e) Pustakawan akan memberikan surat peringatan. Biasanya perpustakaan akan memberikan surat peringatan setelah melewati 7 hari batas pengembalian. Diikuti dengan peringatan kedua dan ketiga selang 7 hari. f) Pustakawan memberikan sanksi kepada pemustaka yang merusak atau menghilangkan buku. g) Pustakawan bertanggung jawab terhadap dokumen peminjaman seperti buku tamu, dokumen anggota, uang denda keterlambatan, uang dendam perusakan atau penghilangan buku, dan kartu anggota yang hilang. h) Pustakawan membuat data statistika peminjaman. Setiap perpustakaan mempunyai kebijakan tersendiri perihal hal tersebut. i) Layan silang atau peminjaman antar perpustakaan untuk memenuhi kebutuhan koleksi sesuai dengan permintaan pemustaka. j) Pustakawan mengawasi barang bawaan pemustaka. k) Pemustaka melakukan tugas lainnya berkaitan dengan layanan peminjaman seperti penyusunan buku ke rak yang sesuai.

Sebelumnya sudah ada penelitian mengenai layanan sirkulasi perpustakaan khusus dengan judul "Kegiatan Layanan Sirkulasi di Perpustakaan Khusus Sekretariat DPRD Provinsi Sumatera Barat" oleh Fadel Muhammad Satria. Penelitian lain mengenai layanan perpustakaan secara keseluruhan dengan judul "Layanan Perpustakaan Perguruan Tinggi dalam menghadapi Pandemi Covid-19" oleh Putut Suharso (2020), kemudian penelitian dengan judul "Peran dan Strategi Layanan Perpustakaan STARKI pada Masa Pandemi" oleh Arvaeni Pakpahan (2020) . Kelebihan yang terdapat pada penelitian sebelumnya ialah para pemustaka dapat dengan mudah memilih judul buku secara langsung. Namun jika berada dikondisi pandemi ini layanan sirkulasi luring akan 
sulit dijalankan bagi perpustakaan yang tidak memiliki koleksi dalam bentuk digital. Maka dari itu pada topik penelitian kali ini yang membedakan dengan penelitian sebelumnya ialah inovasi terbaru proses atau mekanisme yang mengkhususkan pada layanan sirkulasi daring perpustakaan khusus yaitu perpustakaan anak-anak di masa pandemi Covid-19 di Indonesia. Penelitian ini diharapkan dapat menyempurnakan penelitian terdahulu agar terdapat gambaran bagaimana seluruh Perpustakaan dapat menerapkan layanan sirkulasi baik dilakukan secara luring maupun daring.

Fenomena terkait layanan Grab and Go yang akan dikaji dalam penelitian ini terdiri atas 1) Mengapa layanan Grab and Go hadir di Pustakalana Children's Library? 2) Bagaimana layanan Grab and Go hadir di Pustakalana Children's Library? Penelitian mengenai fenomena layanan Grab and Go bertujuan untuk memaparkan inovasi layanan perpustakaan khusus ditengah pandemi Covid-19, memaparkan mekanisme kerja layanan Grab and Go, memberikan informasi mengenai sasaran Layanan Grab and Go, memberikan penjelasan tentang kendala Pustakalana Children's Library selama memberikan layanan Grab and Go, dan memberikan informasi mengenai perbedaan layanan sirkulasi daring khususnya Grab and Go dengan layanan peminjaman buku sebelum di terapkannya layanan Grab and Go.

\section{METODE PENELITIAN}

Penelitian Grab and Go sebagai Alternatif Peminjaman Buku Pustakalana Children's Library menggunakan metode penelitian kualitatif melalui studi kasus. Menurut Yin dalam Saheb, Slamet, \& Zuber (2013) studi kasus merupakan teknik penyelidikan suatu fenomena dalam kehidupan nyata, berbagai sumber dapat digunakan pada penyelidikan sebuah kasus, dan tidak ada perbedaan yang terlalu jelas antara fenomena dengan konteks nyata. Penelitian melalui studi kasus menggunakan pertanyaan How atau Why. Layanan Grab and Go ini merupakan suatu fenomena nyata yang dapat dijumpai oleh pengguna. Layanan Grab and Go ini merupakan ciri khas dari Pustakalana karena layanan sirkulasi daring perpustakaan anak yang memanfaatkan web serta bekerja sama dengan kurir pengiriman dalam kegiatan peminjaman buku-buku anak yang sebelumnya belum pernah dijumpai pada perpustakaan anak.

Penelitian dilakukan dengan cara mewawancarai informan yaitu Direktur Pustakalana Children's Library, Pustakawan Pustakalana Children's Library serta Penanggung Jawab Customer Reasearch Pustakalana Children's Library. Kegiatan penelitian ini mengkaji layanan sirkulasi daring perpustakaan khusus anak yaitu Grab and Go milik Pustakalana Children's Library sebagai objek penelitian. Penelitian 
dilaksanakan di Pustakalana Children's Library pada tanggal 30 Oktober 2020 hingga 27 November 2020. Teknik pengumpulan data dalam penelitian ini adalah wawancara dan studi literatur. Wawancara merupakan interaksi tanya jawab antara dua orang atau lebih dengan orang yang belum dikenal untuk mendapatkan sebuah informasi (Hardani, 2020).

Wawancara sebagai cara untuk mendapatkan informasi dengan menggunakan panduan wawancara melalui aktivitas tanya jawab antara penanya atau pewawancara dengan penjawab atau responden. Ketika melakukan penelitian menggunakan metode kualitatif deskriptif maka tidak menggunakan sebutan populasi (Sugiyono, 2008) melainkan menggunakan istilah informan karena hasil penelitian tersebut tidak akan diberlakukan kepada suatu populasi akan tetapi akan diberlakukan di tempat yang memiliki permasalahan kondisi sosial yang sama dengan hasil penelitian. Jenis wawancara yang digunakan ialah wawancara terpimpin yaitu wawancara terarah dengan menyiapkan panduan wawancara yang sistematis.

Teknis analisis yang digunakan ialah analisis model Miles and Huberman. Model ini menjelaskan tiga alur analisis data yaitu:

1. Reduksi data. Menurut Riyanto dalam Hardani (2020) reduksi data merupakan suatu tindakan merampingkan data yang diperoleh, menyederhanakan, dan data tersebut diabstraksi.

2. Penyajian data. Setelah data yang diperoleh dari wawancara dan sudah melewati tahap reduksi, kemudian data tersebut disajikan dalam bentuk teks naratif.

3. Penarikan simpulan dan verifikasi. Pada tahap ini menghubungkan hasil penjabaran analisis how dengan why. Serta menekankan hasil penelitian yang didukung oleh sumber terpercaya agar menjadi simpulan kredibel.

\section{HASIL DAN PEMBAHASAN}

Layanan Grab and Go tercipta dari pembatasan bersosial di kota Bandung. Pengguna dilarang untuk mendatangi Pustakalana secara langsung, akan tetapi Pustakalana diharuskan untuk tetap melayani kebutuhan informasi pengguna akan koleksi-koleksi yang dimiliki dan pengguna pun meminta kepada Pustakalana untuk tetap dapat memanfaatkan koleksi buku Pustakalana dari rumah. Maka dari itu Direktur Pustakalana Children's Library membuat sebuah inovasi layanan peminjaman buku yang dapat diakses di rumah tanpa harus bertemu secara langsung. Pengguna diharuskan terlebih dulu menjadi anggota Pustakalana jika ingin meminjam buku koleksinya. Setelah itu pengguna mengisi form yang telah disedikan oleh Pustakalana dalam web 
nya. Di dalam form tersebut berisi mengenai identitas pengguna, jenis keanggotaan dan pemilihan buku yang akan dipinjam. Setelah melewati tahap pengisian form, pengguna hanya tinggal menunggu konfirmasi dari pihak Pustakalana. Setelah itu Pustakalana akan mengirim buku-buku yang dipinjam melalui kurir ke alamat pengguna. Dengan demikian kebutuhan informasi pengguna akan koleksi yang dimiliki Pustakalana tetap dapat terpenuhi.

Berdasarkan pengamatan tentang jenis-jenis perpustakaan beserta ciri-ciri nya, jika dilihat konsep perpustakaan khusus yang dikemukakan oleh Sulistyo-Basuki (1991) maka Pustakalana Children's Library dapat dikelompokkan kedalam perpustakaan khusus karena pemustaka ditujukkan untuk kelempok tertentu yakni anak-anak. Namun Pustakalana Children's Library pun dapat dikategorikan menjadi perpustakaan swasta atau pribadi jika dilihat dari sudut pandang keanggotaan. Pustakalana Children's Library termasuk kedalam perpustakaan swasta atau pribadi karena menghidupi perpustakaan dengan sistem member atau keanggotaan berbayar, penjualan merchandise, pengadaan program kegiatan bagi anggota serta diadakan Friends of Pustakalana Library yang merupakan kegiatan donasi yang diadakan oleh Pustakalana Children's Library.

Sebelum masa pandemi Covid-19 Pustakalana memperbolehkan masyarakat khususnya anak-anak selain anggota Pustakalana untuk membaca buku di tempat. Namun terdapat kebijakan yang dibuat oleh Pustakalana ialah buku-buku dapat dipinjam serta dibawa pulang kerumah bagi anak-anak yang tergabung menjadi anggota Pustakalana Children's Library. Sehubungan dengan masa pandemi ini, maka Pustakalana tidak membuka layanan baca ditempat. Oleh karena itu Pustakalana Children's Library menciptakan alternatif pelayanan peminjaman koleksi buku. Layanan Grab and Go merupakan produk inovasi yang diciptakan oleh Pustakalana Children's Library ialah sebuah layanan sirkulasi perpustakaan berbasis daring. Layanan Grab and Go ini diciptakan di masa pandemi agar pemustaka tetap bisa meminjam buku dari rumah. Pelaksanaan Grab and Go dimulai pada tanggal 16 Juni 2020 sekaligus menjadi pertanda pemberlakukan sirkulasi daring dilaksanakan. Layanan Grab and Go dibuka setiap hari senin dan selasa pada pukul 12.00 - 15.30 WIB. Berkaitan dengan pemustaka Grab and Go, Claudine selaku Pustakawan Pustakalana Children's Library mengatakan bahwa layanan Grab and Go dikhususkan bagi anak-anak dalam rentang usia tiga tahun sampai 12 tahun yang tergabung kedalam keanggotaan Pustakalana Children's Library.

Pemustaka diwajibkan untuk mengikuti beberapa tahap ketika akan menggunakan layanan Grab and Go. Pemustaka terlebih dahulu harus bergabung 
menjadi anggota Pustakalana Children's Library. Pada tahap awal pemustaka mengakses "Formulir Sirkulasi Online Pustakalana (New Member)" yang tertera pada bio Instagram @pustakalanalibrary. Pengisian formulir ini meliputi pengisian identitas orang tua pemustaka. Orang tua pemustaka diharuskan mencantumkan alamat rumah lengkap, alamat email, nomor Whatsapp, nama anak yang akan menjadi anggota Pustakalana, tanggal lahir anak, serta jenis keanggotaan yang akan dipilih oleh pemustaka. Pemustaka dibagi menjadi dua bagian yaitu berdomisili di Bandung dan Jabodetabek. Pembagian domisili pemustaka bertujuan untuk menyesuaikan dengan biaya keanggotaan, deposit anggota, biaya admin, biaya peminjaman buku setiap bulan khusus pemustaka domisili Bandung, biaya keanggotaan 6 bulan dengan tiga kali pengiriman buku dengan lima buah buku dalam satu kali pengiriman khusus untuk pemustaka domisili Jabodetabek dan jenis keanggotaan yang akan diinginkan oleh pemustaka.

Jenis keanggotaan yang didaftarkan oleh pemustaka akan berpengaruh terhadap banyaknya koleksi buku yang dapat dipinjam ketika menggunakan layanan Grab and Go. Bagi pemustaka yang berdomisili di Jabodetabek, hanya ada jenis keanggotaan Kancil saja. Jenis keanggotaan Kancil meliputi 3 kali peminjaman dengan 5 buku setiap 1 kali peminjaman selama 6 bulan masa keanggotaan terhitung sejak awal mendaftar. Sedangkan bagi pemustaka yang berdomisili di Bandung, keanggotaan dibagi menjadi 4 jenis yaitu:

a. Koala. Jenis keanggotaan ini berlaku selama 12 bulan dari tanggal pendaftaran. Pemustaka dengan jenis keanggotaan ini khusus untuk anak umur kurang dari 3,5 tahun. Pemustaka dengan jenis keanggotaan Koala hanya bisa meminjam 4 buku setiap bulan nya.

b. Kelinci. Keanggotaan jenis Kelinci hanya bisa meminjam 5 buku setiap bulan nya dan masa berlaku keanggotan 3 bulan terhitung awal mendaftar.

c. Beruang. Pemustaka diperbolehkan meminjam 6 buku setiap bulan nya. d) Kangguru. Jenis keanggotaan ini berlaku selama 12 bulan terhitung sejak awal pendaftaran dan diperbolehkan meminjam buku sebanyak 8 buku setiap bulan nya.

Setelah pemustaka melewati tahap keanggotaan, kemudian pemustaka diarahkan menuju mekanisme Grab and Go. Pemustaka diharuskan mengisi identitas serta jenis keanggotaan yang sebelumnya sudah dipaparkan. Pustakawaan akan menyiapkan 1 bundle yang berisi 8 buku untuk anggota dengan jenis keanggotaan Kangguru, 4 buku untuk keanggotaan Koala, 6 buku untuk anggota dengan jenis keanggotaan Beruang dan 5 buku untuk keanggotaan Kelinci dan Kancil. Grab and Go tidak dibuka setiap saat. 
Pustakalaa membagi kedalam beberapa sesi yang dinamakan batch. Setiap batch dilakukan 4 kali dalam satu bulan yaitu setiap minggu nya.

Batch pertama sudah dilaksanakan pada tanggal 16 Juni 2020 hingga per 17 November 2020 sudah memasuki batch ke-22. Namun setiap satu anggota diharuskan untuk meminjam selama satu bulan. Misalnya ketika ada member A yang meminjam buku pada batch pertama, maka ia diperbolehkan untuk meminjam kembali pada batch kelima. Peraturan tersebut mengantisipasi tidak terpenuhi nya keinginan pemustaka terhadap ketersediaan koleksi. Setelah pemustaka mengisi formulis Grab and Go maka pemustaka diarahkan untuk memilih tema buku bacaan kemudian buku bacaan akan dikirimkan.

\section{"Pustakalana di masa pandemi ini gak menerima pengunjung langsung ditempat. Jadi ya akhirnya kami nyari cara gimana nih supaya pengguna bisa tetep pinjam buku kami. Akhirnya lahir lah layanan Grab and Go ini. Kami sudah mencantumkan step by step nya di form secara jelas. Karena pengguna kita kan anak-anak ya, jadi pasti akun pengguna nya dipegang sama Ibu atau Ayah nya. Ya jadi kita mencamtumkan semuanya jelas di form. Form nya bisa diakses di IG kita atau laman web kita." (Claudine, personal communication, November 11, 2020)}

Berdasarkan hasil wawancara mengenai kebijakan sirkulasi online Grab and Go dengan Claudine Pustakawan Pustakalana Children's Library, khusus di masa pandemi Pustakalana tidak membuka layanan pembacaan ditempat. Pemustaka diharuskan mengembalikan buku bacaan setelah masa peminjaman habis yaitu melebihi 1 bulan, karena tidak diperbolehkan untuk memperpanjang masa peminjaman. Pemustaka yang sudah selesai membaca dan ingin mengembalikan buku terlebih dahulu melakukan konfirmasi dengan admin Pustakalana, mengisi link Pengembalian dan Peminjaman Buku, selanjutnya buku bacaan dapat dikirimkan melalui kurir pengiriman pada jam kerja Pustakalana yang sudah ditentukan. Apabila pemustaka terlambat mengembalikan buku maka akan dikenakan denda sejumlah nominal yang sudah ditentukan.

Begitu pun jika sampul depan buku rusak, satu lembar halaman robek, atau pun halaman buku hilang maka dapat dikenakan denda berupa penggantian sampul buku atau mengganti dengan buku yang sama. Grab and Go tidak mengizinkan pemustaka untuk memindahtangankan buku bacaan yang dipinjam kepada orang lain demi meminimalisir penyebaran Covid-19. Pada mekanisme pelayanan Grab and Go pun dijelaskan bahwa ketika pemustaka akan meminjam buku, maka pemustaka memilih berdasarkan tema atau subjek buku yang sudah disediakan daftar nya oleh pustakawan. 
Kemudian pustakawan yang akan memilih judul buku yang sesuai dengan pilihan tema pemustaka.

Kebijakan layanan sirkulasi online Grab and Go mempunyai tantangan tersendiri bagi pihak Pustakawan maupun Pemustaka. Pustakawan dituntut harus lebih memahami serta cepat tanggap dalam memenuhi keinginan pemustaka dalam hal pemilihan buku berdasarkan permintaan tema, karena pemustaka tidak dapat datang langsung ke perpustakaan untuk memilih judul buku bacaan. Selain itu pun pustakawan sedikit kesulitan ketika akan mengingatkan pengembalian buku karena mayoritas akun keanggotaan pemustaka dipegang oleh orang tua nya yang memiliki kesibukkan masingmasing. Para pustakawan pun diliputi rasa khawatir mana kala buku yang dikirimkan ataupun dikembalikan hilang pada saat proses pengiriman oleh kurir.

"Di masa pandemi ini ya mau gamau pengguna harus lebih ekstra kalau mau minjam buku. Dulu cuman dating, langsung dapet buku. Sekarang harus ngisi form yang sudah dibuat lalu menunggu buku datang diantar oleh kurir. Ya karena itu, banyak pengguna yang merasa alur peminjaman buku nya semakin ribet." (Alif, personal communication, November 11, 2020)

Berdasarkan wawancara dengan Alif selaku Penanggung Jawab Customer Reasearch Grab and Go dijelaskan pada keadaan dahulu pemustaka hanya tinggal datang ke perpustakaan, memilih buku yang diinginkan, kemudian menunjukkan kartu keanggotaan, lalu sudah dapat membawa pulang bahan bacaannya. Kini setiap pemustaka yang notabene dibantu oleh orang tua nya harus melalui tahapan secara online dengan mengisi formulir. Terkadang buku yang sampai pun belum sesuai dengan keinginan karena pemustaka hanya memilih berdasarkan tema bukan judul serta membaca sekilas tentang isi buku bacaan. Pembentukan Grab and Go didasari oleh pembatasan sosial masyarakat.

Pemustaka untuk saat ini tidak bisa lagi mendatangi perpustakaan secara langsung seperti sebelum kedatangan masa pandemi Covid-19. Pustakalana telah membuat kebijakan peminjaman buku secara daring. Maka dari itu layanan Grab and Go dijadikan cara lain atau alternatif layanan sirkulasi oleh Pustakalana Children's Library agar pemustaka dapat menggunakan koleksi bacaan Pustakalana. Pustakawan merasa terbantu dengan adanya Grab and Go di tengah pandemi Covid-19. Alif, penanggung jawab Customer Research mengatakan dalam sesi wawancara bahwa perpustakaan merasa sangat terbantu dengan layanan Grab and Go setelah diadakan survei penyebaran kuisioner. Pada dasarnya layanan Grab and Go ini masih termasuk kedalam 
layanan sirkulasi sebuah perpustakaan, hanya saja yang menjadi pembeda antara layanan sirkulasi luring dengan daring ( $G r a b$ and Go) terlihat dari beberapa kegiatan pustakawan.

Jika mengacu kepada kegiatan sirkulasi yang dikemukakan oleh Sulistyo-Basuki (1991) dan Hartono (2016) sebelumnya, terdapat beberapa hal yang berbeda dari pelaksanaan kegiatan sirkulasi pada umumnya. Perbedaan tersebut terlihat dari perubahan "bentuk" kegiatan sirkulasi. Pustakawan Pustakalana Children's Library tidak perlu melakukan pengawasan terhadap pemustaka yang datang serta keluar masuk Pustakalana karena di kondisi saat ini Pustakalana Children's Library tidak menerima kunjungan pemustaka secara langsung. Terlepas dari perbedaan layanan sirkulasi, pemustaka sangat terbantu dengan adanya layanan Grab and Go ini.

Apabila di masa pandemi Covid-19 ini terdapat pemustaka yang baru saja ingin menjadi anggota, maka pemustaka tersebut tidak mendapatkan kartu anggota dalam bentuk fisik serta perpustakaan tidak akan terlebih dahulu mengirimkan surat ke alamat rumah sebagai tanda pengecakan kebenaran alamat pemustaka. Pemustaka akan dikirimkan ID keanggoatan dalam bentuk eletronik. Pada tahap peminjaman, pemustaka tidak perlu datang langsung ke Putskalana Children's Library hanya cukup mengakses link yang sudah disediakan. Selanjutnya untuk pemustaka yang hendak mengembalikan buku terlebih dulu harus melakukan konfirmasi dengan pustakawan melalui nomor WhatsApp ataupun email Pustakalana Children's Library. Hal tersebut berbeda dengan kegiatan pengembalian pada umumnya yang mengharuskan pemustaka datang langsung untuk menyerahkan buku.

Pemustaka tidak diberikan kesempatan untuk memperpanjang buku bacaan, berbeda dengan yang Sulistyo-Basuki (1991) jika buku lazimnya boleh diperpanjang selama dua kali. Pustakawan pun tidak perlu memeriksa koleksi buku tandon atau buku yang hanya boleh dibaca ditempat karena pustakawan tidak memasukkan buku dengan edisi terbatas sesuai dengan pilihan tema pemustaka. Pada proses kegiatan penarikan denda, pustakawan memberlakukan denda terhitung setelah melewati batas pengembalian. Pemberian denda sebanyak Rp5.000,- per hari setelah melewati masa peminjaman untuk 1 bundle buku. Pustakawan tidak mengeluarkan peringatan dalam bentuk surat yang dikirim satu kali, dua kali dan seterusnya kepada pemustaka seperti yang dikemukakan oleh Sulistyo-Basuki. Namun pustakawan setiap hari Jumat dan Sabtu mengirimkan link pengembalian dan peminjaman buku sekaligus sebagai tanda peringatan melalui fitur broadcast pesan WhatsApp. 
Claudine sebagai Pustakawan Pustakalana Children’s Library mengatakan “Kirakira ada 1000 buku yang ter-sirkulasi ya. Jadi buku-buku itu hasil data keluar masuk.” Artinya terdapat 1000 buku yang dipinjam serta dikembalikan selama masa Grab and Go ini. Pemustaka yang menggunakan layanan Grab and Go sudah ada 25 pemustaka dari total keseluruhan pemustaka yang aktif sebagai anggota. Claudine telah mencatat bahwa pemustaka berumur 4 sampai 10 tahun yang sering meminjam buku bacaan Pustakalana. Secara umum tema buku yang sering dipinjam adalah fabel, fantasi, dan cerita keseharian. Namun pada pemustaka umur 3 tahun sering meminta buku bacaan tentang pembelajaran konsep seperti pengenalan angka, pengenalan huruf, perlawanan kata (seperti in out dan up down). Secara keseluruhan buku bacaan yang dimiliki Pustakalana Children's Library berbahasa Indonesia, Inggris serta terdapat beberapa bahasa Jerman. Pemaparan tersebut termasuk kedalam proses pembuatan statistika peminjaman yang dikemukakan oleh Sulistyo-Basuki. Pustakalana Children's Library tidak mengajukan permintaan peminjaman kepada Perpustakaan lain. Serta kegiatan pengawasan terhadap barang bawaan pemustaka pun tidak dilakukan oleh pustakawan karena tidak ada pemustaka yang berkunjung secara langsung.

\section{SIMPULAN}

Layanan Grab and Go merupakan layanan peminjaman buku secara daring. Layanan Grab and Go ini diciptakan oleh Pustakalana Children's Library karena keterbatasan dalam aktivitas akibat pandemi. Pemustaka dilarang untuk mengunjungi langsung Pustakalan, akan tetapi pemustaka sangat membutuhkan informasi yang berasal dari koleksi buku. Pustakalana mencari cara agar kebutuhan pemustaka tetap terpenuhi. Dengan demikian tercipta suatu inovasi layanan sirkulasi daring yang dapat digunakan walau hanya di rumah saja, inovasi ini dinamakan Grab and Go. Layanan Grab and Go ini hadir karena keterbatasan berinteraksi secara tatap muka langsung. Grab and Go mengharuskan pemustaka untuk mengakses form yang disediakan oleh Pustakalana. Selanjutnya pemustaka memilih buku yang akan kemudian serta mengisi identitas diri. Setelah itu Pustakalana akan mengirimkan buku-buku yang dipilih ke alamat pemustaka. Dengan begitu Grab and Go dapat dirasakan layanan nya oleh pemustaka.

Adanya layanan Grab and Go tersebut membuat Pustakalana tetap dapat menjalankan kegiatan sirkulasi walau ditengah kondisi pembatasan sosial karena Covid19, menghubungkan pemustaka dengan Pustakalana Children's Library, serta mempermudah penyebarluasan informasi khususnya buku bacaan anak-anak kepada pemustaka. Penelitian selanjutnya disarankan untuk dapat lebih mengkaji mengenai 
inovasi-inovasi layanan yang dimiliki perpustakaan khusus saat mengalami kesulitan akibat pandemi. Agar khalayak umum mengetahui perkembangan dari segala jenis layanan perpustakaan khusus.

\section{Kontribusi Pada Keilmuan}

Penelitian ini merupakan kajian dalam bidang perpustakaan yang mengkaji layanan perpustakaan. Hasil penelitian ini dapat menjadi dasar untuk penelitian selanjutnya atau penelitian bidang sejenis mengenai inovasi-inovasi layanan di perpustakaan khusus yang memiliki kesulitan akibat adanya pandemi. Penelitian ini juga dapat menjadi sumber inspirasi bagi penelitian bidang lain yang berhubungan dengan layanan perpustakaan.

\section{Pernyataan Minat Kajian}

Peneliti bernama Zahra Fahira Iskandar memiliki minat kajian dalam bidang Layanan Perpustakaan. Peneliti bernama Sukaesih memiliki minat kajian dalam bidang Literasi Informasi, Dokumentasi, Kearsipan, dan Layanan Perpustakaan. Peneliti bernama Evi Nursanti Rukmana memiliki minat kajian dalam bidang Childrens Literature. Peneliti bernama Samson CMS memiliki minat kajian dalam bidang Dokumentasi Budaya, Komunikasi Budaya, dan Sistem Pengetahuan Masyarakat Lokal.

\section{Kontribusi Peneliti}

Peneliti dengan nama Zahra Fahira Iskandar melakukan survei dan wawancara. Peneliti dengan nama Sukaesih, Evi Nursanti Rukmana, dan Samson CMS memberikan arahan, masukan dan koreksi terhadap penelitian yang dilakukan.

\section{DAFTAR PUSTAKA}

Azanella, L. A. (2020). Update corona dunia 20 Oktober 2020: 40,6 juta orang terinfeksi. Belgia alami "tsunami" Covid-19. Retrieved November 1, 2020, from https://amp.kompas.com/tren/read/2020/10/20/083800665/update-corona-dunia-20oktober-2020--40-6-juta-orang-terinfeksi-belgia

Hardani. (2020). Metode penelitian kualitatif \& kuantitatif(1st ed.). Yogyakarta: Pustaka Ilmu Group Yogyakarta.

Hartono. (2016). Manajemen Perpustakaan Sekolah: Menuju Perpustakaan Modern \& Profesional. (R. KR, Ed.) (1st ed.). Yogyakarta: Ar-Ruzz Media.

Loho, A. M., Tabaga, A., \& Harinda, S. (2016). Persepsi pemustaka terhadap kualitas pelayanan referensi di perpustakaan Universitas Negeri Manado. Acta Diurna, 5(1), $1-9$.

Retrieved

from

https://ejournal.unsrat.ac.id/index.php/actadiurnakomunikasi/article/view/10926/10 516

Pakpahan, A. (2020). Peran dan strategi layanan perpustakaan STARKI pada masa pandemi. TarFomedia, 1(2), 37-39.

Pranita, E. (2020). Diumumkan awal Maret, ahli: virus corona masuk Indonesia dari Januari. $\quad$ Retrieved November 1, 2020, from https://amp.kompas.com/sains/read/2020/05/11/130600623/diumumkan/awa/maret-

Grab and go alternatif layanan peminjaman buku Pustakalana Children's Library di masa pandemi (Zahra Fahira Iskandar, Sukaesih, Evi Nursanti Rukmana, Samson CMS) 
ahli--virus-corona-masuk-indonesia-dari-januari

Rahmah, E. (2018). Akses dan layanan perpustakaan (1st ed.). Jakarta: Prenadamedia Group.

Rajasa, M. A. (2020). Tangkal corona, PSBB Bandung Raya mulai berlaku hari ini. Retrieved November 1, 2020, from https://m.cnnindonesia.com/nasional/20200422071248-20-495899/tangkal-coronapsbb-bandung-raya-mulai-berlaku-hari-ini

Saheb, Slamet, Y., \& Zuber, A. (2013). Peran modal sosial bagi petani miskin untuk mepertahankan kelangsungan hidup rumah tangga di pedesaan Ngawi (studi kasus di Desa Randusongo Kecamatan Gerih Kabupaten Ngawi Provinsi Jawa Timur). Jurnal Analisa Sosiologi, 2(1), 17-34.

Sugiyono. (2008). Metode penelitian pendidikan: pendekatan kuantitatif, kualitatif dan $R \& D$. Bandung: Alfabeta.

Suharso, P., Ariffiyana, I. P., \& Wasdiana, M. D. (2020). Layanan perpustakaan perguruan tinggi dalam menghadapi pandemi Covid-19. Anuva Jurnal Kajian Budaya, Perpustakaan Dan Informasi, 4(2), 271-286. https://doi.org/10.14710/anuva.4.2.271-286

Sukaesih. (2020). Konsep dan hakikat layanan informasi dan perpustakaan. Bandung.

Sulistyo-Basuki. (1991). Pengantar ilmu perpustakaan (1st ed.). Jakarta: Gramedia Pustaka Utama.

WHO. (2020). Coronavirus. Retrieved November 1, 2020, from https://www.who.int/health-topics/coronavirus

Wulandari, R., Rohanda, \& Sumiati, T. (2012). Layanan sirkulasi dalam upaya pemenuhan kebutuhan informasi pengguna di perpustakaan Institut Manajemen Koperasi Indonesia (IKOPIN). EJurnal Mahasiswa Universitas Padjadjaran, 1(1), 18. 